\title{
NOTES ON THE SAN CARLOS APACHE
}

\author{
By ALEŠ HRDLIČKA
}

\section{INTRODUCTION}

During my visit to the San Carlos Apache in $1900,{ }^{1}$ and especially while conducting researches into the physical anthropology of this people during the earlier part of $1905,{ }^{2}$ I embraced the opportunity of making some collateral observations of an ethnologic and archeologic nature. As the San Carlos people and the country occupied by them are but little known to ethnologists, these notes may prove of interest.

The San Carlos Apache occupy largely the rugged country extending southwestward from the White mountains in Arizona, between that part of Salt river known as Black river, and the Gila. This section forms a part of the great White Mountain Apache reservation. The principal settlements are in the valley of the Gila, from the abandoned Fort Thomas to a few miles beyond San Carlos agency, and in the valley of San Carlos creek or river. The people are officially represented as consisting of the San Carlos, Coyotero, and Tonto Apache, and in 1904 numbered 1,718 individuals. They subsist by agriculture or by working for the whites on the railroad, and at mines, the agency, and the schools, while the older members receive rations from the Indian Department. The people in general are peaceable and are advancing toward civilization; they are common-sense and clever, and are less hampered in their progress by aboriginal traditions, beliefs, and observances than other southwestern Indians, notably the Pueblos. The Apache are also industrious, but are still as improvident as Indians generally. Their morals suffer by the proximity of the railroad and mining towns, and especially by lack of restraint on the manufacture among them of tulipi (tesvino, tiszein). This

\footnotetext{
1 Under the auspices of the Hyde Expedition for the American Museum of Natural History, New York.

2 Expedition of the Bureau of American Ethnology.
} 
liquor, made by fermenting corn in a peculiar way, is rendered more intoxicating by the addition of roots, and sometimes by the admixture of the vile whisky sold surreptitiously by the whites. Abuse in the use of this drink is the cause of practically all disorder, violence, and degradation in the tribe.

The San Carlos Apache know not whence they came. Fifty years ago many of them lived on upper Salt river; some claim the land they had there to this day, and would like to return. One of the men said he heard from the elders that they formerly lived in what is now the vicinity of Flagstaff, at the base of the San Francisco mountains, whence they went eastward, and finally came to the Salt and Gila rivers.

Only traces of their tribal organization remain. Of the divisions of the tribe known to whites as Coyoteros, Tontos, etc., the Indians have little knowledge. No clans exist. The people were divided into numerous small bands, known by some geographic peculiarity of the sections claimed by them as their chief seats, and each under a chief. Some of the chiefs were selected by reason of their prowess in war. A number of the bands and chiefs are still nominally recognized; their names and location are as follows :

\section{Bands among the San Carlos and nearest related Apache}

I. $C e-\bar{e} \bar{y}_{-} k i-d n, T c e-c e-\bar{e} Y-k i-d n$, " "projection of a mountain," "promontory" ; live about Talklai ; chief, Čil-ču-a-ni.

2. Til-se-ke-ced-lan, "two mountains (together)"; live about a mile below Talklai; chief, Antonio.

3. S-čes-čce-ne, "rocky hill"; live about Geronimo (a part of the so-called Coyoteros); no chief.

4. Ce-yi-n, Ce-yin, "cañon hollowed in rock" ; live about Geronimo (a part of the Coyoteros); chief not known.

5. Tes-cih, "red paint" (red vegetal dye, used in facial painting and basketry); live in Cibicu valley; chief, Norman Cassido.

6. Ti-dn-a-ye, "bend over from a hill into a valley"; live near San Carlos; no chief.

7. Kaž-na-ho-ti-ln, "valley of willows"; live between Talklai and San Carlos; mixed; no chief known.

'See Hrdlička, Method of Preparing Tesvino among the White River Apaches; American Anthropologist, vi, 1904, pp. 190-1.

2 For key to pronunciation see American Anthropologist, v, 1903, p. 4 I9. 
8. Na-tah-na-di-ti-ln, "cross the river with mescal"; some live at White Mountain; chief, Talklai.

9. Ha-gus-te--le, "head of the valley"; live above Talklai ; chief,

10. $K a-i-d n-c_{i}$, "rows of trees"; live in the upper part of San Carlos valley; chief not known.

12. Ce-bi-naž-ti-e, "surrounded by rocks"; live 4 miles above San Carlos, in San Carlos valley; no chief.

12. Kai-ha-te-in, "growing-up trees" (trees of a certain variety, along the river); nothing definite is now known about this band.

13. Thle-dil-go-žn, "junction of two valleys" (where a "wash" joins the river); nothing definite known about it.

Of several of these bands only a few individuals survive, and these are scattered or have joined other bands.

\section{DWELLINGS}

The usual dwelling of the San Carlos Apache is known as a khiva, but it is also called by the borrowed term tipi. It is made, by the women, of slender, freshly-cut poles and green branches or brush. In ground-plan the khúva is slightly oval, measuring 10 to 12 feet in the longer and 8 to 9 feet in the shorter diameter. The structure is 9 to to feet high, and hemispherical to bluntly conical in form. Occasionally at the entrance there is a small, straight or curving extension which serves as a windbreak. The poles forming the framework of the khúva are generally of green willow from which the bark has been peeled; these are stuck in the ground, 2 or $21 / 2$ feet apart, and the tops bent over and tied together with anything handy. There are no forked supports and no regular crossribs, but occasionally some of the sticks are bent and intertwined with or laid obliquely upon the others. A slight opening is generally left between the saplings at the top for the escape of the smoke.

The erection of the dwelling, the women say, is easy enough; it takes but a single day. It is regarded as women's work, and that is why they, and not the men, build it. When the superstructure is finished, the interior is excavated to the depth of 12 to 18 inches, and most of the earth piled against the base of the structure, making it solid and keeping out water during rains. In winter, the khúva is made smaller, in order that it may be warmer; in summer 


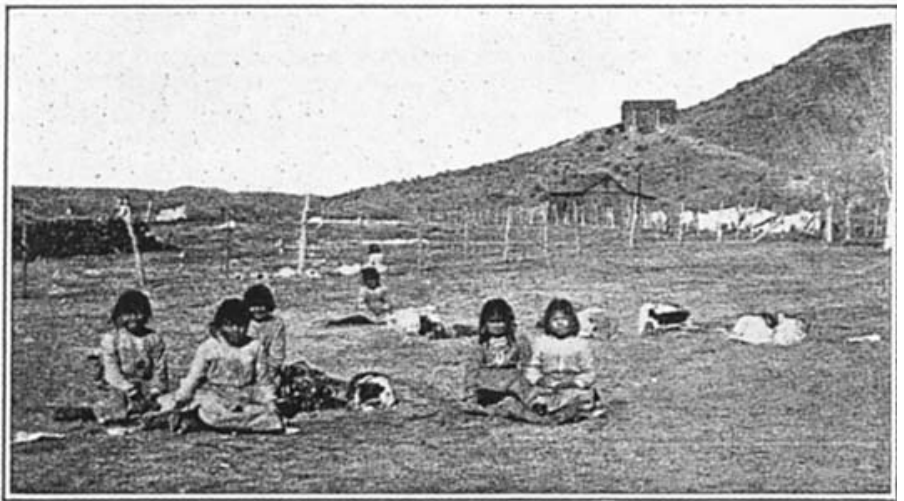

x. School girls playing at house-building.

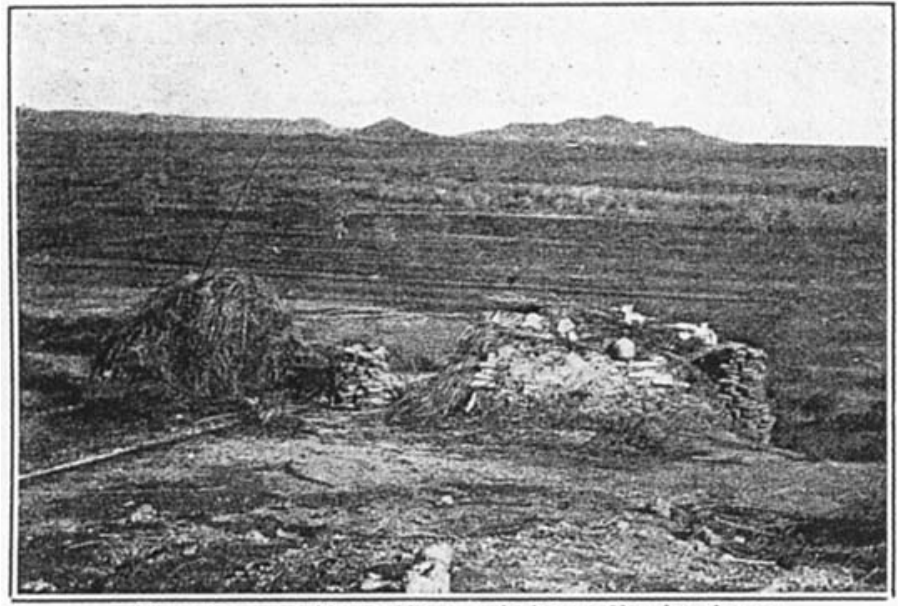

2. Recently occupied brush khíra, and a house of brush and stone.

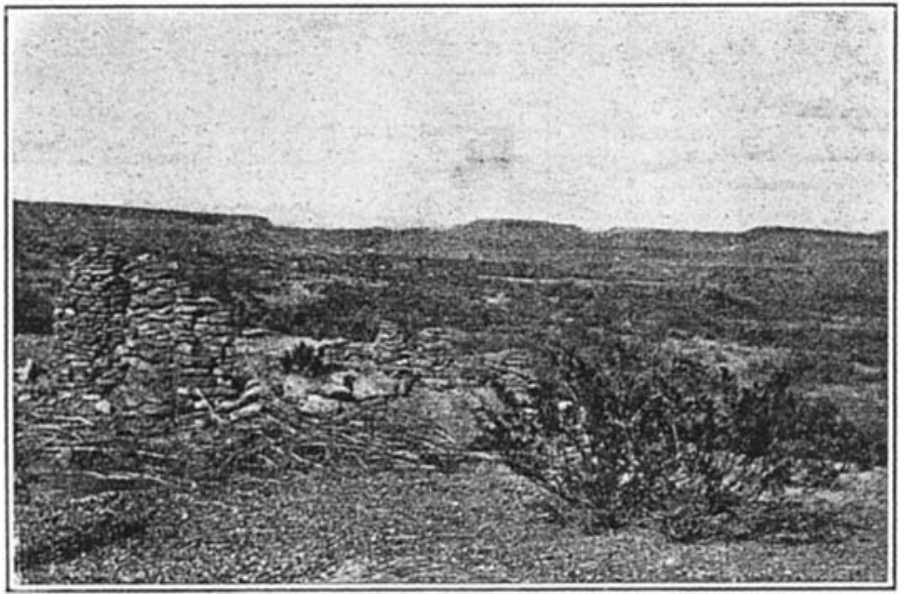

3. Ruins of a recent Pueblo-like stone dwelling 

they build it larger, so as to give more shade and ventilation. In rainy weather it is covered as much as possible with sheets of canvas. No symbolism is connected with any part of the house, and no ceremony attends the entering into a new dwelling; in one family, however, it was said that they always make a prayer when going into a new khúva, and in one of the dwellings I saw two eagle feathers, undoubtedly a fetish, tied to one of the upright poles.

These simple Apache dwellings, except during heavy rain, are comfortable and cheerful, and owing to the cottonwood and willow branches with which they are covered, are pleasantly fragrant. The light is subdued, but may be easily increased by spreading the branches. The doorways are always low, enabling ready closure and insuring warmth, particularly at night. The doors usually face the west, because the prevailing winds in this region are from the east.

Although the khúva is a light structure, it is sometimes occupied for a considerable period. If an accident befalls it, as sometimes happens through fire or flood, or if it becomes necessary to burn it and its contents on account of the death of an occupant, or to abandon it by reason of the removal of the family to another locality, the loss is inconsiderable.

The dwellings are built generally in groups of three to six, forming camps, which, according to the Indians, are occupied by "friends," i. e., related families. In a number of instances a family lives in a khúva near a plank house built by the Government, which it prefers to use for storage purposes.

The San Carlos Apache have also a few quadrilateral dwellings with nearly flat roofs, but these were most probably introduced by the Yuma or the Mohave. There are likewise in San Carlos valley the ruins of several recent stone dwellings, standing singly but built much like the houses of the Pueblos. A similar structure, built partly of stone and partly of brush, is still inhabited (plate $\mathrm{xxx}, 2$ ).

According to chief Čil-ču-a-ni, his people, in his childhood (about 50 years ago), built the same kind of khúvas as they do to-day. They did not construct dwellings of stone or adobe until after coming into more intimate contact with the whites.

The khúva is also the customary dwelling of the White Moun- 
tain Apache of Arizona. It is less common, especially in winter, among the Mescaleros in New Mexico, many of whom live in tents; and it is never built by the Lipan, who formerly lived, they say, only in tipis of buffalo hide. The Jicarillas, who also dwell chiefly in tents, sometimes erect brush houses somewhat similar to the khúva, but of different shape.

\section{MANUFACTURED OBJECTS}

In old objects of their own manufacture the San Carlos Apache are very poor. All that could be found or learned of were a few of the characteristic hemispherical caps, a few violins and flutes, and some nicely decorated saddle-bags. Their utensils are almost entirely those made by the whites, or are modifications of them. An exception occasionally seen is a nicely made gourd ladle, or spoon, the handle and border of which bear an incised decoration in simple geometrical figures.

Basketry. - The women make a limited number of baskets of several varieties. They weave a conical, household carry-all basket, called tha-tca, 2 to $2 \mathrm{I} / 2$ feet high, decorated with one to four bands $I$ to $I 1 / 2$ inch broad, of simple geometric figures in black, brown, reddish, or blue, parallel with the border. The coiled border is strengthened by the inclusion of a stout stick or, in more recent time, of a heavy wire hoop. A buckskin fringe and border are occasionally added as a further decoration. This basket is carried on the back, a strap or string that is attached to one side passing over the forehead, and is used chiefly for carrying wood. Sometimes, in event of the death of its maker, it is placed on her grave.

Another and more common type of basket is a nicely decorated, more or less concave plaque, made almost entirely for sale. The decoration is in black (catsclaw), sometimes in black and brown (catsclaw and yucca), and the figure, as among other Apache, is usually some modification of a star-like motive. The workmanship in some of these flat baskets is excellent.

The third variety is the olla- or jar-shaped basket, with a decoration of simple geometric pattern in black (catsclaw) and, rarely, in brown (yucca). Some of these are of large size and 
command a high price; one, 38 inches in height and very well made, was sold during my last visit, by the woman who made it, for fifty dollars. The plaque and olla are both of coil-work, the carry-all is twined weaving.

The osiers used in the basketry are principally of the willow (ka-jih) and the cottonwood (tes). The shoots are cut in winter and made into bunches of 15 to 20 by the women; these bunches are eventually bent into broad rings, placed in a pot, and slightly boiled in order that they may be easily peeled with the fingers, occasionally aided by the teeth. They are then split with the teeth, and the flat outer splints, placed in bunches of 30 or 40 , are washed thoroughly in cold water, dried in the sun, and stored for future use. The brownish red yucca root, called bi-ka-ak-te, is used only occasionally in basketry. The catsclaw (ce-gol-sha-ha) osiers are not boiled, but after having been softened in water are split in the same way as the willow sticks, and are likewise tied in small bundles until needed.

The designs on the baskets, both those used and those kept for sale, have no symbolic meaning; they are intended merely for decorative effect. A few of the basketry designs are identical with those seen among the Pima. The red coloring is produced with the $\check{c} i$ plant; the rarer blue with the ordinary washing blue; the yellow, restricted to the buckskin fringes, with a vegetal dye or an aniline color.

Basket-making is taught to a girl by her grandmother or mother from the time she is five or six years of age. She is first given young plants of the $e-k a-i e$ co-še, a yucca (the spiny points of which are chewed off in order that they may not hurt her), the leaves of which she learns to interweave. The first style of basket that a young girl learns to make is the tha-tca. Coiled basketry, intended for sale, she does not learn to weave until quite grown.

The White Mountain Apache make basketry similar to that of the San Carlos people; among the Mescaleros and Jicarillas, however, while the decorative figures are related, the materials and workmanship of the baskets are wholly different.

The old San Carlos women say they always made some decorated baskets for use in the household; but the fine work with 
human or animal figures, as well as several of the shapes, originated with the demands of trade.

Two of the coiled plaques collected for the National Museum were made, one in the writer's presence, by an old woman totally blind. Both are well woven, are of pleasing shape, and are decorated in simple geometric designs with martynia.

Baby-board. - The baby-board among the San Carlos Apache, called $p i$-tca, or pi-tcal, consists of an elliptical willow frame (me-tca), within which are fastened, close together, transverse ribs $(k a-p a-n e)$, whittled from a soft wood that grows along the streams. The hood of the cradle ( $p i-t h a-n a-n a$, or pi-tca-na-na) is made usually by bending a number of reeds, placing them side by side, and fastening them together in several rows with sinew. Occasionally the hood is woven from fresh reeds or branches in much the same manner as among the Walapai. The hood may be painted red with $c i$ or left uncolored.

The baby-board is generally finished the first or second day after the birth of the child. In most instances it is entirely new, but sometimes the frame of an old cradle is utilized. The first cradle-board is approximately the size of the baby, but when the child outgrows it the mother makes a larger one. Before the baby is placed on the board the base is covered with fine cedar bark, or grass, or pieces of old cloth, or even excelsior, over which are placed several layers of old calico. Under the head of the child are generally laid several folded pieces of calico, and to the hood is attached a screen of muslin for the protection of the infant's face. Being now placed on the cradle-board, the body and feet of the child are covered with two or more layers of old but clean calico, and then it is laced to the board. To facilitate the lacing there is usually attached to the sides of the cradle-frame a strip of canvas or, rarely, buckskin, with holes along the free border. These flaps extend partly over the covering of the child, and being laced together, serve to hold it securely. The lacing is usually tight enough to prevent free movement of the body. The child is laid prone on its back, with its arms along the sides, thus leaving only the head free. In this position the infant is constantly kept, except during the three to five times that it requires attention in its wak- 
ing hours of the day, when it is unlaced, cleansed, and allowed freedom for a while. As the child grows older and strong enough to be held in a sitting position on the mother's lap, its intervals out of the cradle become longer, and they increase again, except at night, when the child is able to sit alone. The time for entirely discarding the cradle approaches when the child begins to stand and walk; only exceptionally will a child of I 5 to 18 months still be put in the cradle a part of the day or night.

While laced on the cradle-board the child sleeps a large part of the time; if the lacing be loosened, it usually becomes restless until laced up again. For this reason the infant is kept on the cradleboard at night, for otherwise, the women say, it would disturb the mother's sleep. While the child is sleeping, the cradle-board is laid upon the ground and the front lap of the hood is dropped to protect the face from flies and the light.

The pressure of the back of the head on the calico folds results, in time, in cranial deformation know as occipital compression, which is central or lateral according to whether the child habitually rested its head at the back or on one side. It is remarkable that among the older Apache, who were reared during the restless times when the people were compelled to move frequently from place to place, carrying the children with them, occipital deformation is much less common and less pronounced than among the younger generation.

Pottery. - The San Carlos Apache made ordinary pottery until about twenty years ago, since which time the industry has gradually ceased. This consisted of undecorated cylindrical cooking jars of medium size, with convex to nearly conical bases. The material used in the manufacture of this pottery was river mud, to which was added a decoction of Spharalcea emoryi, called by them $i$-sá-pith-az-ne-he, or $i-z \dot{e}-p i t h-a z-n e-h e$, which signifies "medicinemix-in-making-jar." This plant was collected on the mesas, ground up, roots and all, and boiled with a little water. The liquid was mixed with the clayey mass, and also rubbed on the vessel, inside and out, before burning; this was supposed to make the ware tougher and less pervious.

Musical Instruments. - The musical instruments of the San 
Carlos Apache are a flageolet and a peculiar one-string violin. The former, made of cane, is usually 15 to 20 in. $(38$ to $50 \mathrm{~cm}$.) long, and decorated with geometric designs cut in the surface and colored, chiefly in blue and red. Plate xxxi illustrates a good example of these instruments, obtained from one of the Talklai policemen, who knew well how to play it.

According to Mr E. H. Hawley, specialist in musical instruments in the National Museum, this instrument is a primitive flageolet. It is made of a straight piece of cane between five joints. The two distal septa in each half (first and second, fourth and fifth) have been removed, while the third, situated near the middle, remains. The openings, each $5 \mathrm{~mm}$. in diameter, are made in one side, one above the other, immediately below and above the middle partition, across which they are connected by a groove $4 \mathrm{~mm}$. wide and deep. A band of tanned deer-skin, $1.7 \mathrm{~cm}$. broad, from which a number of tassels hang as a decoration, is fitted about the body of the flute, at the middle, and can be slid up and down within certain limits. This band, which is essential to the production of the sound of the instrument, is so placed by the player that it covers the opening above the middle septum and also the groove, leaving the lower aperture to act as a sound hole; it thus forms a whistle of the tube, according to Mr Hawley. In the lower third of the instrument, and in line with the central openings, are four fingerholes, each $5 \mathrm{~mm}$. in diameter, the centers of which are situated $9.7,13.5,16.4$, and $18.3 \mathrm{~cm}$. below the lower lip of the sound hole. The most distal aperture is closed with a wooden plug. All the openings, as well as the central groove, were pierced with a red-hot iron. Of the decorations the most prominent is the maltese cross, the symbol of a star. This flute is $48 \mathrm{~cm}$. long and 2 $\mathrm{cm}$. in average diameter.

The one-string violin is made of a piece of light, hollow wood, preferably a stalk of the agave. The body is usually a cylinder, 5 to $6.5 \mathrm{~cm}$. in diameter and 30 to $35 \mathrm{~cm}$. long, both ends of which are stopped with wooden disks. The string is of horse-hair, tightened over a small wooden bridge. The bow consists of a small arched reed, or stick, with a few strands of horse-hair. When played, the violin is held in the left hand, which is kept semiflexed. 


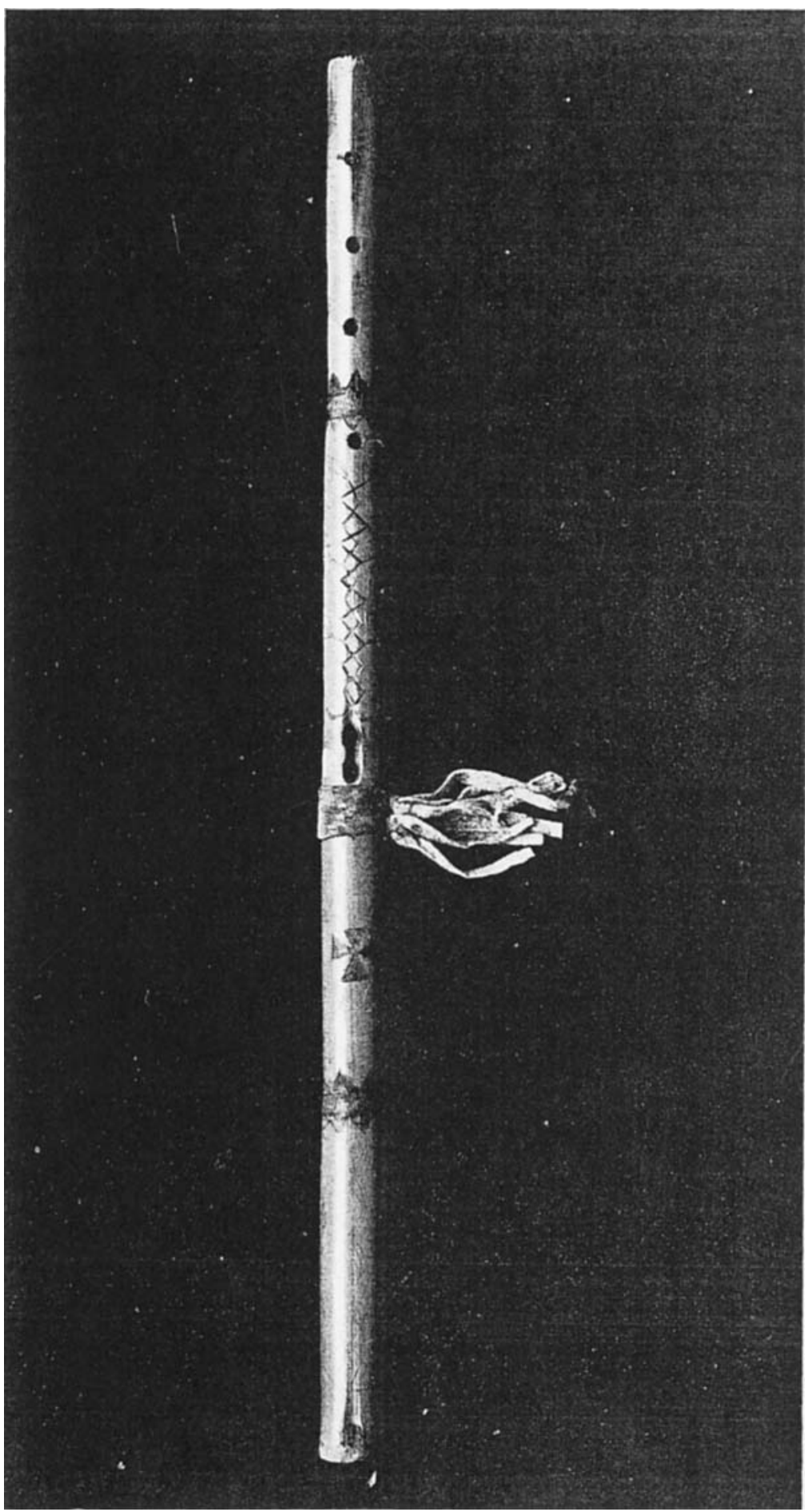

FLUTE OF THE SAN CARLOS APACHE 

The tunes produced with this instrument by a good player are characteristic and quite complex.

Besides the flageolet and single-string violin, a few of the Apache also have a small violin like that of whites, and closely resembling an instrument used among several of the Indian tribes in Mexico. The Apache themselves regard this instrument as of Mexican origin. The school girls and young women are fond of the jews'-harp.

\section{HABITS AND CUSTOMS}

The San Carlos Apache, especially the younger element, preserve but few of their ancient habits and customs. They have no distinctive ceremonies or dances, not even such as are still observed by their White Mountain relatives. The writer heard of a few medicine-men and one medicine-woman who still have recourse to incantations and fetishes, and are feared by the people at large. Witchcraft and the efficacy of fetishes are believed in, but scarcely more than among the lower classes of whites. A belief in spirits, especially bad spirits, or čin-dis, exists, and number four, and to a lesser extent eight, have more or less mystic significance. Of folklore there are tales about the coyote, owl, badger, etc. The owl is said to "talk good Apache." One that had been killed was tied on a line near a settlement, possibly as a protection against something. Two badgers that had been killed by the Apache were hung by their tails in the brush along a road.

Numerous observations, of physiological or medical interest, on the food and mode of life of this people are reserved for a more comprehensive account, but a few brief statements on various customs will here be presented.

Hair Dressing. - The hair of the San Carlos women is trimmed to the level of the shoulders. The girls and younger women comb the front hair over the forehead and cut it in line with the eyebrows, in the form of a "bang," while the remainder is allowed to fall naturally at the sides and back.

Old women simply brush or comb the hair backward. The hair of the men is always trimmed and permitted to hang at the sides and back without " banging." Bandana handkerchiefs are used as head-bands by some of the men.

AM. АNTH. N. S., 7-33 
Tattooing. - The custom of tattooing did not exist among the old San Carlos people, but it is now very common among the young, especially the school girls. The people say the habit was learned from the Mohave settled near San Carlos. The tattooing is done on the glabella, forehead, middle of the cheek, chin, and back of the hand. The girls either tattoo themselves or one another, the materials employed being a needle or a cactus spine, and ink or charcoal. The figures are good copies of those seen among the Mohave, but their meaning is not known. If the figure somewhat resembles a letter of the alphabet, the children will say that it represents that character. They also tattoo, particularly on their hands, actual letters, and even names of sweethearts and relatives.

Record-keeping. - In one family a record of the age of the last child was kept by the father, by marking on a paper the number of "moons" since the birth of the child. Each moon was indicated by a cross, and a large dot was made for each tenth moon.

Mother-in-law Taboo. - The taboo concerning the mother-in-law seems to be reciprocal. Should a young man persist in speaking to his mother-in-law, the latter, with her family, might send him away as "no good," saying they "don't want such a son-in-law."

If she is to live with her married daughter, the mother builds her hut near-by, but in such a way that the door faces another direction, thus enabling the son-in-law, on coming out of his dwelling, to avoid catching sight of her.

Puberty Feast. - Among most of the Apache a feast is celebrated when a girl reaches puberty, but among the San Carlos people the custom has apparently been abandoned.

Play of Children. - While visiting the dwellings of the people, and the schools, the writer often observed groups of children at play, but no highly specialized native children's games were seen. The girls play more than the boys, and, except about the schools, playmates are restricted to children of the same family or to relatives. The oldest child has charge of the group. Play of all kinds is greatly enjoyed, though quarrels sometimes occur. On the whole the manifestations of the Indian child at play differ little from those of the white child, unless it be in the exercise by the former of greater patience and perseverance. 
The boys play with bow and arrow, marbles, and ball, and at running. Girls play hide and seek, and with pebbles, cans, and dolls; they also make dolls, cradles, and houses, and when a supply of good mud is available, model tiny effigies of women, men, dolls, horses with their riders, other animals, and various implements and utensils. In these much ingenuity, deftness, and attention to detail are exhibited.

If, while running about in the brush, a stranger approaches, the girls, of whatever age, become quiet in an instant, and each drops flat behind a bush or other object, hiding quietly and motionless until the intruder has passed. If they find that he has seen them, they scatter with all rapidity; if one tries to catch them, they cry out angrily; and if actually caught, will fight with all their means and strength.

The principal play of the girls is the building and furnishing of miniature houses; with sticks, leaves, grass, and twigs they construct khúvas and shelters, often with remarkable faithfulness of detail, placing in the former miniature furniture and finally domiciling therein a doll-baby. About the schools (plate xxx, 1) where more girls congregate, entire villages, striking in their picturesqueness, are built daily.

Dolls are made by tying tufts of certain plants near the top, or from rags. With pebbles the girls play "jacks," much as white children do.

With slight modification these details concerning the play of children apply to all the Apache as well as to other southwestern Indians.

Training of Children. - A boy among the San Carlos Apache is taught by his father and grandfather the various things he is supposed to know or to be able to do. This instruction begins as soon as the boy can talk. The first thing he learns is to count. When "big enough" (without reference to his having reached puberty), the boy goes out with his father, who teaches him to run on flat ground, and then up and down hill. $\mathrm{He}$ is encouraged to break branches from trees, so as to become strong; to jump into cold water, that he may lose fear and learn to swim; and is taken out early in the morning and taught to race. The boy also 
learns to cut wood, to farm, and to do many other things a knowledge of which he will find necessary later in life; but the prime object of his training, which differs according to circumstances, is to make him able, strong, and fearless.

The girl is trained by her mother, and especially by her grandmother. As with the boy, the training begins very early, practically as soon as the child can understand and control its movements; but it is never systematic nor severe. The little one is made to rise early in the morning and fetch water, and gradually she is taught to aid in the household duties - in cooking and in the care of the younger children. As before mentioned, when she is five or six years of age she receives her first lesson in simple basketry; but the manufacture of decorated baskets and saddle-bags, and of beadwork and clothing, she is not taught until womanhood approaches.

Burials. - The burials of the San Carlos Apache are never found very near the habitations, and sometimes they are four or five miles distant. The dead are placed in natural rock shelters in the cliffs, in convenient rock crevices, on a rocky mountain side, in the earth or talus at the base of a hill, or in nooks of small, unfrequented cañons.

Two of the cañons near Talklai contain together more than eighty burials. Graves of men, women, and children occur in the same locality, though they are seldom close together, and some are entirely isolated. When a burial is to be made on a hillside, the talus and earth are removed until a platform large enough to receive the body is formed. On this the remains are placed, and over them is constructed a rude frame of rafters and brush, which is covered with rocks, forming a heap 4 to 10 feet broad, 6 to 15 feet long, and $2 \mathrm{x} / 2$ to 4 feet high (plate xxxII, I). Earthen graves usually are constructed in a similar manner, and are also partly covered with stones. In a few years the framework of the grave becomes decayed and falls in.

The body is taken to the place of burial by men on horses, or in a wagon, usually early in the morning following the day or night of death. No coffin is used, and nothing is placed beneath the body, which is clothed as at the time of death. If the remains be those of a man, they are also wrapped in a Navaho blanket and in 


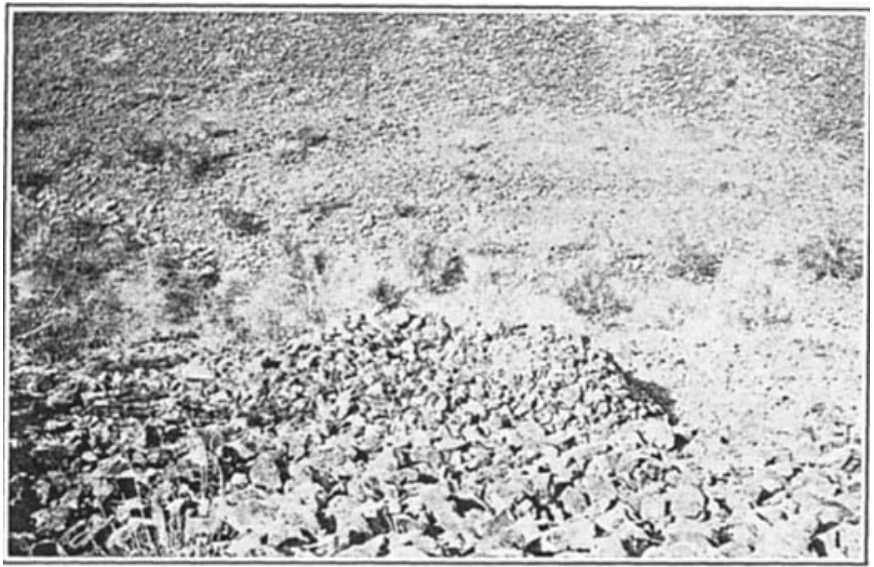

1. Stone grave of an adult.

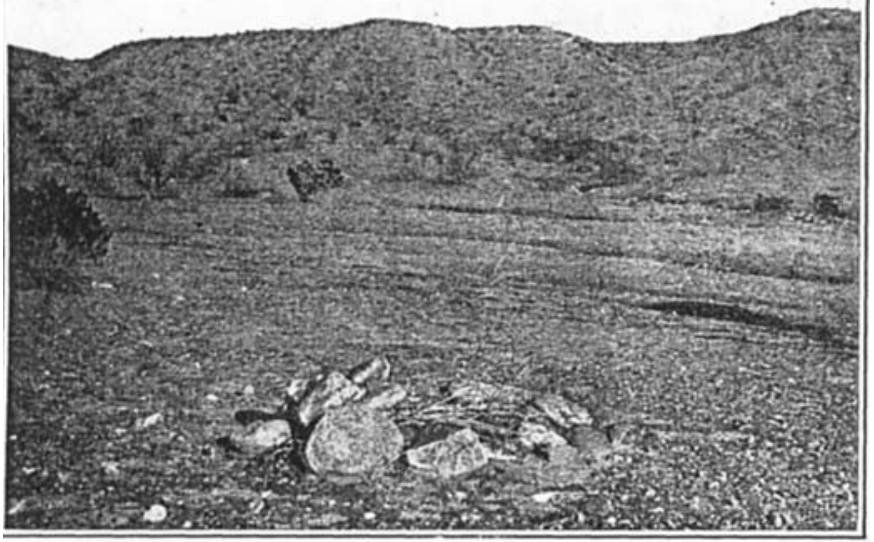

2. Grave of an infant

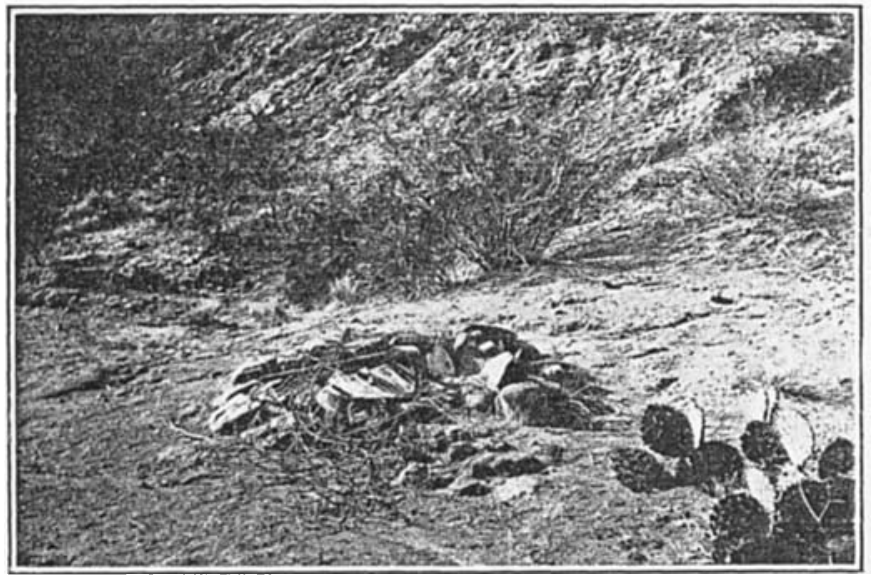

3. Infant's grave, with tradle-board and shovel deposited thereon. 

one or two woolen blankets or a quilt, and over all is placed a covering of canvas or heavy cotton. A woman is also buried in the garments with which she was clothed at the time of death, accompanied with her beads, and the body is likewise wrapped with blankets or cloth; but there are not so many of these articles as in the case of a man. When a child dies it is dressed in numerous spare articles of its clothing and is abundantly covered. On the grave of a man is usually found the shovel with which the grave was dug, occasionally also an ax; on a woman's grave, an ax and sometimes a carrying basket ; on the grave of a little child, a cradleboard; and on or in the grave of a larger child several tin cups and pans. No further attention is given to the grave or to the remains. Tree burial, which occurs among the White Mountain Apache, is not practised by the San Carlos people, and cremation is unknown.

\section{ANTIQUITIES}

With the exception of the portion that lies within San Carlos valley, the San Carlos reservation is poor in antiquities, the country not having been adapted to extensive sedentary settlement. No petroglyphs were observed within the reservation, nor indeed in much of the adjacent region of the White mountains.

In San Carlos valley and the neighboring flats of the Gila, archeologic remains, consisting of ruined habitations and burial mounds, are more numerous. The habitations were in small clusters and larger villages. At least two villages of considerable size once existed in San Carlos valley, the ruins of one of them being still traceable within the grounds of the Indian school near Talklai.

The ruins of these habitations are marked on the surface by single or double rows of stones and by low mounds of moderate extent. The settlement near Talklai consisted of perhaps 200 houses. No regularity is observable in the ground-plan of the village; often two or three dwellings are connected, but each such group faced in a different direction. All the dwellings were apparently of one story. The rooms were quadrilateral, some nearly square, and averaged 8 by 10 feet in size. The walls were massive, reaching a maximum of two feet in thickness. The masonry consisted of slabs of unworked stone of varying size, laid vertically in adobe mortar. The stones were obtained from the nearby river. 
These dwellings, the floors of which are now 2 to $2 \mathrm{y} / 2$ feet beneath the surface, are completely filled with soil and debris. The mounds represent clusters of such dwellings.

When dug into, the rooms of the houses were found generally to contain a simple corner fireplace, near which potsherds were usually unearthed. In some of the few cases in which excavation was conducted, sherds of pottery were the only reward. In one room, however, there was found on the floor about half of the skeleton, in a poor state of preservation, of a person of small stature. At some distance from these bones and about a foot above the level at which they were encountered, there was embedded in the clay, in a vertical and apparently undisturbed position, a small jar of coiled ware filled with earth and covered with a small slab of stone. Another room yielded, in addition to a few potsherds, a polished double-bladed ax.

Slight excavation conducted in the slope of one of the mounds exposed several rooms, each of which contained pottery vessels and one or more metates and manos. The pottery is chiefly mediocre, and in some instances quite crude; but there were also pieces of better quality, neatly decorated in white, black, and several shades of red. In two of the rooms a large jar was found partly filled with calcined human bones; both jars were covered, one with a smaller jar, the other with a fragment of a bowl.

Several rooms in the Talklai ruin had previously been excavated by teachers in the Indian school. In some of them were found entire pieces of pottery, and in at least one room a jar containing burned human bones. On the surface of the ruin, and in the piles of stones that had been carted there from part of it that had been converted into an orchard, the writer found several stone axes ranging from crude to finely polished, a number of stone pestles of similar workmanship, many grinders varying in shape and size, and other stone objects, all of which are now in the National Museum. A number of large, deep, broken mortars were found in the debris. A striking feature of the excavations was the great rarity of stone chips and the total absence of arrow and spear points and knives, apparently indicating that the energies of the people in implement making were directed largely toward those 
employed in domestic life. Some arrowpoints have been found on the neighboring mesas by the teachers and children, but their origin is uncertain.

From what was seen of the other ruins, they are identical in character with those here described. Some have been dug into and pottery containing burned human bones were found. At San Carlos, on the Gila, a large jar of coiled ware, containing cremated human bones and covered with a bowl, was found in digging by school children, and at the time of my visit was in possession of Dr S. B. Weeks, superintendent of the school. ${ }^{1}$ It may here be remarked that a somewhat similar burial was unearthed early in the present year at Sacaton, on the Gila, three days' journey southwestward from San Carlos. These call to mind burials of a kindred nature found by Mr F. H. Cushing in Salt river and Gila valleys for the Hemenway Expedition, by Dr J. Walter Fewkes in the vicinity of Solomonsville on the Gila for the Bureau of American Ethnology, and a recent single find near Fort Apache. It points to a former widespread custom, among the ancient inhabitants of this section, of cremating their dead and burying the remains in jars, while at the same time some non-cremated dead were buried in the rooms.

When questioned about the ruined habitations and the people who abandoned them, the Apache profess total ignorance. They say that when they first came into the country the ruins were just as they are today. Their name for the old people is $N a-i l l h-k i$-de, which means " ancient ones." The fact should not be overlooked, however, that their traditions are meager. Many of the men who would have preserved their lore were killed during their almost incessant warfare, and the younger element know little beyond personal recollection.

U. S. National Museum,

Washington, D. C.

I Several similar burials have since been discovered in this locality, and some of the calcined bones and potsherds obtained have just been received from Dr Weeks by the National Museum. 